\title{
Use of vermicompost for the removal of toxic metal ions of synthetic aqueous solutions and real wastewater
}

\author{
Luane Patricia Guedes Barbosa ${ }^{1}$, Tácila Oliveira Pinto de Freitas ${ }^{1}$, Madson de Godoi Pereira \\ ${ }^{1}$ Bahia State University, Department of Exact and Earth Sciences, 2555 Silveira Martins St, Salvador, Bahia, Brazil \\ +Corresponding author: Madson de Godoi Pereira, e-mail address: madson.pereira444@gmail.com
}

\section{ARTICLE INFO}

Article history:

Received: February 20, 2018

Accepted: May 31, 2018

Published: June 28, 2018
Keywords:

1. humified organic matter

2. metals

3. wastewater treatment

ABSTRACT: Samples of vermicompost were used to decontaminate aqueous media containing $\mathrm{Cd}^{2+}, \mathrm{Cu}^{2+}, \mathrm{Mn}^{2+}, \mathrm{Ni}^{2+}, \mathrm{Pb}^{2+}$ and/or $\mathrm{Zn}^{2+}$ ions at concentration up to $10 \mathrm{X}$ higher than the limits of National Council of the Environment (Resolution 430/2011). For this purpose, $50.00 \mathrm{~mL}$ of synthetic solutions ( $\mathrm{pH} 0.9$ just after preparation) and wastewater from a chemical laboratory were stirred with dried vermicompost $(\sim 10.0000 \mathrm{~g})$, without sieving or with diameter $\leq 0.053$ $\mathrm{mm}$. Aqueous media were treated with vermicompost, either at rest $(24$ to $96 \mathrm{~h})$ or under mechanical agitation $(2$ to $10 \mathrm{~h})$. All elements were spectrometrically determined in the different supernatants. In the synthetic solutions, except for $\mathrm{Mn}^{2+}$ and $\mathrm{Zn}^{2+}$, concentrations were lower than the legal limits or than the limits of detection, when vermicompost without sieving was used. After treating synthetic solutions with sieved vermicompost, $\mathrm{Cd}^{2+}, \mathrm{Cu}^{2+}, \mathrm{Ni}^{2+}, \mathrm{Pb}^{2+} \mathrm{e} \mathrm{Zn}^{2+}$ ions concentrations were undetectable, while $\mathrm{Mn}^{2+}$ concentrations were too close to the legal limits. In the wastewater, $\mathrm{Cd}^{2+}$ and $\mathrm{Pb}^{2+}$ concentrations, which were 1.5 and $3.8 \mathrm{X}$ higher than the legal limits, respectively, were undetectable after treatment with vermicompost without sieving. Besides its efficiency of retaining the evaluated cations, vermicompost was able to increase the aqueous media $\mathrm{pH}$ from 0.9 to $6.0 \pm 0.5$.

\section{Introduction}

Human activities have caused harmful impacts on the environment, with emphasis on aquatic ecosystems, which are frequently recipients of several types of liquid disposal. Of the various aquatic pollutants in this disposal, metallic elements deserve special attention due to their high potential for bioaccumulation and biomagnification, as well as the fact that these elements are responsible for the appearance of various diseases in humans ${ }^{1}$. Therefore, aqueous disposal contaminated with metals must be efficiently treated and, among the available treatment modalities, those that use adsorption stand out for their operational simplicity and high efficiency. When adsorbents of natural origin are used, adsorption processes also have a very low $\operatorname{cost}^{2}$.

Many naturally occurring adsorbents have been successfully used for the removal of metal cations from aqueous media, including clays ${ }^{3}$, plant biomass ${ }^{4}$ and material enriched with humified organic matter ${ }^{5}$. . Humified organic matter is formed by the chemical and microbiological decomposition of different organic precursors, such as proteins, carbohydrates and lipids. These precursors are fragmented, and the fragments are randomly recombined to form highly stable and complex molecular structures ${ }^{2}$.

Humified organic matter is divided into three classes, according to solubility criteria against the $\mathrm{pH}$ of the medium. Thus, humics are insoluble irrespective of $\mathrm{pH}$, whereas fulvic acids have a 
high solubility over a wide $\mathrm{pH}$ range. In turn, humic acids are soluble in alkaline or slightly acidic media. The structures of humics, in relation to the structures of fulvic acids, have higher carbon content, while the number of hydrophilic groups is considerably lower. The structure of humic acids has an intermediate percentage of both carbon and hydrophilic groups ${ }^{7}$.

Among the different ways of obtaining humified materials is vermicomposting, in which certain earthworm species ingest a mixture of soils and organic residues (e.g., cattle manure). In the digestive tract of these animals, a broad and diverse microbial population is responsible for accelerating the fragmentation of organic molecules and the formation of humified compounds. After excretion of the ingested and metabolized material by the worms, the vermicompost is obtained, with high levels of humified organic matter, in addition to high concentrations of nutrients such as calcium, magnesium, potassium and sodium. Additionally, the vermicompost has a high surface area and this property favors adsorption processes ${ }^{8}$.

In view of the above, this study evaluated the efficiency of vermicompost in adsorbing $\mathrm{Cd}^{2+}$, $\mathrm{Cu}^{2+}, \mathrm{Mn}^{2+}, \mathrm{Ni}^{2+}, \mathrm{Pb}^{2+}$ and $\mathrm{Zn}^{2+}$ ions from aqueous media. Therefore, mixed synthetic solutions were used, as well as real wastewater (potentially contaminated with these metal cations) originated from an atomic absorption spectrometry laboratory. This study was conducted under high acidity conditions, which is characterized as a limiting factor for adsorption efficiency. Thus, this study differs from others for offering an interpretation of the adsorption potential of vermicompost under conditions commonly found in complex matrices of many wastewaters generated by chemical laboratories.

The six elements chosen for this study are of environmental relevance, as they can all cause serious damage to human health, if they are discarded at high concentrations in water sources, with their consequent pollution. In this context, cadmium and lead are very toxic, and can lead to infertility, leukemia, bone weakness and/or psychiatric disorders. Although copper, manganese, nickel and zinc are essential within certain limits, the excessive ingestion of these elements can lead to blindness (in the case of copper), while high doses of manganese in the human body lead to neurological diseases. In turn, nickel and zinc contaminations cause humans to develop different types of tumors ${ }^{1}$.

\section{Experimental}

\subsection{Instruments and reagents}

The following instruments were used: water purification unit (Gehaka Master P \& D, Brazil), horizontal shaker table (Quimis Q225M, Brazil), potentiometer (Tecnal Tec-3MP, Brazil) and flame atomic absorption spectrometer (GBC SensAA, Malaysia).

Individual stock solutions of cadmium, lead, copper, manganese, nickel and zinc ions at 1000 $\mathrm{mg} \mathrm{L}^{-1}$ (SPC, USA) were used daily to calibrate the flame atomic absorption spectrometer, as well as to prepare mixed synthetic solutions of $\mathrm{Cd}^{2+}$, $\mathrm{Cu}^{2+}, \mathrm{Mn}^{2+}, \mathrm{Ni}^{2+}, \mathrm{Pb}^{2+}$ and $\mathrm{Zn}^{2+}$ ions. Adjustments of $\mathrm{pH}$ were made with $\mathrm{HNO}_{3}$ solutions, which were prepared from dilution of $14 \mathrm{~mol} \mathrm{~L}^{-1} \mathrm{HNO}_{3}$ (Merck, Germany).

\subsection{Procedures}

Vermicompost sample was characterized ${ }^{9}$ for $\mathrm{pH}$, humidity, total organic matter, and ashes. All analyses were performed in triplicate.

All adsorption tests described in this section were performed with vermicompost previously oven-dried $\left(70{ }^{\circ} \mathrm{C}\right)$ to constant mass. The vermicompost was produced in the city of Lauro de Freitas-BA and purchased in the local commerce of Salvador-BA. Adsorption tests were performed with analytical blanks, using four replicates, and the concentrations of cadmium, lead, copper, manganese, nickel and zinc ions were quantified by flame atomic absorption spectrometry (F AAS). Thus, the spectrometer was operated with an air-acetylene flame at the respective flow rates of 8.0 and $2.0 \mathrm{~L} \mathrm{~min}^{-1}$. All analyses were performed with background radiation correction, using a deuterium lamp, and the hollow cathode lamps were operated at the following wavelengths $(\mathrm{nm}): 228.8(\mathrm{Cd}), 324.8$ $(\mathrm{Cu}), 279.5(\mathrm{Mn}), 232.0(\mathrm{Ni}), 283.3(\mathrm{~Pb})$ and 213.9 $(\mathrm{Zn})$. Calibration curves were built at the following concentration ranges $\left(\mathrm{mg} \mathrm{L}^{-1}\right)$ : 0.1 to 1.5 $(\mathrm{Cd}), 0.5$ to $5.0(\mathrm{Cu}, \mathrm{Mn}$ and $\mathrm{Ni})$, and 1 to $6(\mathrm{~Pb}$ and $\mathrm{Zn}$ ).

In the first phase of the experiments, approximately $10.0000 \mathrm{~g}$ of vermicompost (without going through any sieving step) were placed in contact with $50.00 \mathrm{~mL}$ of mixed solution of $\mathrm{Cd}^{2+}, \mathrm{Cu}^{2+}, \mathrm{Mn}^{2+}, \mathrm{Ni}^{2+}, \mathrm{Pb}^{2+}$ and $\mathrm{Zn}^{2+}(\mathrm{pH} 0.9$ just after preparation) at the respective 
concentrations of $2.0 ; 10.0 ; 10.0 ; 20.0 ; 5.0$ and $50.0 \mathrm{mg} \mathrm{L}^{-1}$. The contacts of the vermicompost with mixed solution aliquots were performed under mechanical stirring $(2,4,6,8$ and $10 \mathrm{~h})$ at $200 \mathrm{rpm}$, as well as at rest (24, 48, 72 and $96 \mathrm{~h})$.

In a second phase of the experiments, $50.00 \mathrm{~mL}$ aliquots of mixed solution of $\mathrm{Cd}^{2+}, \mathrm{Cu}^{2+}, \mathrm{Mn}^{2+}$, $\mathrm{Ni}^{2+}, \mathrm{Pb}^{2+}$ and $\mathrm{Zn}^{2+}$ ions ( $\mathrm{pH} 0.9$ just after preparation), at the respective concentrations of $2.0 ; 10.0 ; 2.0 ; 20.0 ; 5.0$ and $10.0 \mathrm{mg} \mathrm{L}^{-1}$, were stirred $(200 \mathrm{rpm})$ with approximately $10.0000 \mathrm{~g}$ of vermicompost (without going through any sieving step) for $10 \mathrm{~h}$. Volumes of $50.00 \mathrm{~mL}$ of the aforesaid mixed solution were also placed in contact with about $10.0000 \mathrm{~g}$ of vermicompost for $24,48,72$ or $96 \mathrm{~h}$, at rest.

In the third stage of the experiments, approximately $10.0000 \mathrm{~g}$ of vermicompost sieved in a $0.053-\mathrm{mm}$ mesh were placed in contact with $50.00 \mathrm{~mL}$ of mixed solution of $\mathrm{Cd}^{2+}, \mathrm{Cu}^{2+}, \mathrm{Mn}^{2+}$, $\mathrm{Ni}^{2+}, \mathrm{Pb}^{2+}$ and $\mathrm{Zn}^{2+}$ ions ( $\mathrm{pH} 0.9$ just after preparation), at the respective concentrations of $2.0 ; 10.0 ; 10.0 ; 20.0 ; 5.0$ and $50.0 \mathrm{mg} \mathrm{L}^{-1}$. The vermicompost masses and portions of the mixed solution were contacted via mechanical stirring $(10 \mathrm{~h}$ at $200 \mathrm{rpm})$ or at rest $(24,48,72$ and $96 \mathrm{~h})$.

In the fourth and last experimental stage, about $10.0000 \mathrm{~g}$ of vermicompost, without sieving, were mechanically stirred for $10 \mathrm{~h}$ at $200 \mathrm{rpm}$, with $50.00 \mathrm{~mL}$ of real wastewaters generated by the atomic absorption spectrometry laboratory of the Department of Exact and Earth Sciences at the State University of Bahia, Salvador Campus. This wastewater was treated at its natural $\mathrm{pH}$ $(\mathrm{pH}=5.0)$, and after its acidification with drops of $\mathrm{HNO}_{3}$ solution at $1.0 \mathrm{~mol} \mathrm{~L}^{-1}$ until $\mathrm{pH} 1.0$.

After the different procedures described above, the supernatants were filtered on qualitative filter paper, stored in polyethylene bottles (previously decontaminated in a $10 \% \mathrm{v} / \mathrm{v} \mathrm{HNO}_{3}$ bath for $24 \mathrm{~h}$ ) and refrigerated at $4{ }^{\circ} \mathrm{C}$, until the determinations of cadmium, lead, copper, manganese, nickel and zinc by F AAS, under the previously described experimental conditions. In the case of tests with the wastewater from the atomic spectrometry laboratory, they were analyzed by F AAS, before and after the treatment with the vermicompost. At the end of the first experimental phase, supernatants were also analyzed for $\mathrm{pH}$ by immersing a combined glass electrode.

\section{Results and discussion}

The vermicompost, which was used in this study, had the following results (Mean \pm standard deviation, $\mathrm{N}=3$ ) concerning the characterization analyses: $\mathrm{pH}(6.4 \pm 0.2)$, humidity $(52.9 \pm 2.2 \%$, wt./wt.), total organic matter $(55.6 \pm 0.7 \%$, wt./wt.), and ashes $(44.4 \pm 0.7 \%$, wt./wt.). The average $\mathrm{pH}$ indicates deprotonated acidic organic chemical groups (carboxylates, for example), and the high humidity levels corroborate with the presence of these groups, which can establish hydrogen bonds with water molecules. Moreover, the high amounts of hydrophilic organic chemical groups in the considered vermicompost sample can be related to its expressive contents of organic matter. In turn, $44.4 \pm 0.7 \%$ (wt./wt.) of ashes highlight the use of soils in the vermicompost production ${ }^{9}$. Thus, the results of vermicompost characterization support its promising results for treating aqueous media (synthetic solutions and real wastewater) containing $\mathrm{Cd}^{2+}, \mathrm{Cu}^{2+}, \mathrm{Mn}^{2+}$, $\mathrm{Ni}^{2+}, \mathrm{Pb}^{2+}$ and $\mathrm{Zn}^{2+}$ ions as discussed below.

The concentrations of $\mathrm{Cd}^{2+}, \mathrm{Cu}^{2+}, \mathrm{Mn}^{2+}, \mathrm{Ni}^{2+}$, $\mathrm{Pb}^{2+}$ and $\mathrm{Zn}^{2+}$ ions in the mixed solutions, which were used in the first and third experimental phases, corresponded to concentrations 10 times higher than the maximum limits established by Resolution 430/2011 of the National Environmental Council (Conselho Nacional do Meio Ambiente, CONAMA) ${ }^{10}$, whose values are $\left(\mathrm{mg} \mathrm{L}^{-1}\right)$ : $0.2(\mathrm{Cd}), 1.0(\mathrm{Cu}), 1.0(\mathrm{Mn}), 2.0(\mathrm{Ni})$, $0.5(\mathrm{~Pb})$ and $5.0(\mathrm{Zn})$. On the other hand, in the second experimental phase, the concentrations of $\mathrm{Mn}^{2+}$ and $\mathrm{Zn}^{2+}$ were modified for the reasons discussed throughout this section.

All adsorption tests, whose results are discussed below, were performed with $50.00 \mathrm{~mL}$ mixed solutions, since it was found that this volume was sufficient to completely cover vermicompost particles.

The detection limits for cadmium, lead, copper, manganese, nickel and zinc were calculated by analyzing 15 independent blanks. The standard deviation of the analytical signals generated by the blanks was multiplied by three and divided by the slope of the calibration curve for each element ${ }^{11}$. The following detection limits $\left(\mathrm{mg} \mathrm{L}^{-1}\right)$ were obtained: $0.05(\mathrm{Cd}), 0.08(\mathrm{Cu}), 0.1(\mathrm{Mn}), 0.06$ $(\mathrm{Ni}), 0.2(\mathrm{~Pb})$ and $0.05(\mathrm{Zn})$.

Table 1 lists the concentrations of cadmium, lead, copper, manganese, nickel and zinc in the supernatants obtained after the first phase of the experiments. Considering the limits of 
CONAMA $^{10}$, it was concluded that all conditions adopted (under mechanical stirring or at rest) were efficient for the removal of cadmium, copper and nickel. For lead, mechanical stirring tests were successful, while tests at rest were less efficient. This fact indicates that the diffusion of lead, from the mixed solution to the vermicompost particles, is slow, thus requiring constant movement of the liquid mass. In turn, all the conditions tested in the first experimental phase were not successful in reducing the concentrations of manganese in the mixed solution. For zinc, except for the experiments under mechanical stirring for $2 \mathrm{~h}$, all the other experiments yielded unsatisfactory results in relation to the legal limit ${ }^{10}$.

Table 1. Concentrations $\left(\mathrm{mg} \mathrm{L}^{-1}\right)$ of cadmium, copper, manganese, nickel, lead, and zinc after the first experimental phase*, $\mathrm{N}=4$. Values expressed as Mean \pm standard deviation.

\begin{tabular}{ccccccc}
\hline \multirow{2}{*}{$\begin{array}{c}\text { Experimental } \\
\text { condition }\end{array}$} & $\mathrm{Cd}^{2+}$ & $\mathrm{Cu}^{2+}$ & $\mathrm{Mn}^{2+}$ & $\mathrm{Ni}^{2+}$ & $\mathrm{Pb}^{2+}$ & $\mathrm{Zn}^{2+}$ \\
\hline & $0.12 \pm 0.01$ & $0.10 \pm 0.03$ & $>5.0^{* * * * *}$ & $1.4 \pm 0.1$ & $<0.2$ & $1.3 \pm 0.2$ \\
VA** 2h & $0.11 \pm 0.01$ & $0.08 \pm 0.01$ & $>5.0$ & $1.1 \pm 0.2$ & $<0.2$ & $7.0 \pm 0.9$ \\
VA 4h & $0.10 \pm 0.01$ & $0.09 \pm 0.01$ & $>5.0$ & $1.1 \pm 0.1$ & $<0.2$ & $7.1 \pm 0.6$ \\
VA 6h & $<0.05 * * * *$ & $0.03 \pm 0.01$ & $>5.0$ & $0.50 \pm 0.03$ & $<0.2$ & $4.5 \pm 0.2$ \\
VS 8h & $<0.05$ & $0.05 \pm 0.01$ & $>5.0$ & $1.1 \pm 0.2$ & $<0.2$ & $6.9 \pm 0.9$ \\
VA 10h & $0.14 \pm 0.06$ & $0.10 \pm 0.03$ & $>5.0$ & $1.3 \pm 0.4$ & $1.7 \pm 0.2$ & $8 \pm 2$ \\
VR*** 24 h & $0.06 \pm 0.06$ & $0.10 \pm 0.03$ & $3.5 \pm 0.3$ & $0.6 \pm 0.5$ & $0.6 \pm 0.2$ & $5 \pm 3$ \\
VR 48 h & $0.05 \pm 0.01$ & $0.04 \pm 0.02$ & $3.5 \pm 0.1$ & $0.4 \pm 0.1$ & $0.6 \pm 0.1$ & $4.9 \pm 0.5$ \\
VR 72 h & $0.08 \pm 0.01$ & $0.06 \pm 0.01$ & $>5.0$ & $0.7 \pm 0.2$ & $0.7 \pm 0.2$ & $6.0 \pm 0.7$ \\
VR 96 h & & &
\end{tabular}

*Experimental conditions: mechanical agitation of vermicompost without sieving (10.0000 g) at $200 \mathrm{rpm}$ with $50.00 \mathrm{~mL}$ aliquots of mixed solution of $\mathrm{Cd}^{2+}, \mathrm{Cu}^{2+}, \mathrm{Mn}^{2+}, \mathrm{Ni}^{2+}, \mathrm{Pb}^{2+}$ and $\mathrm{Zn}^{2+}(\mathrm{pH} 0.9)$, at the respective concentrations of 2.0; $10.0 ; 10.0 ; 20.0 ; 5.0$ and $50.0 \mathrm{mg} \mathrm{L}^{-1} * *$ Vermicompost under mechanical agitation. ***Vermicompost at rest. $* * * *$ Lower than the detection limit of the analytical method. $* * * * *$ Higher than the highest concentration of the calibration curve.

The concentrations in Table 1 , as well as in Tables 2 and 3, are associated with $\mathrm{Cd}^{2+}, \mathrm{Cu}^{2+}$, $\mathrm{Mn}^{2+}, \mathrm{Ni}^{2+}, \mathrm{Pb}^{2+}$ and $\mathrm{Zn}^{2+}$ ions, since the composition of the synthetic solutions was exclusively aqueous and did not contain binding molecules and/or complex-forming binding ions. This statement can be extended to the wastewater generated by the atomic absorption spectrometry laboratory, whose composition was also exclusively aqueous, derived from the use of standard metal solutions for the calibration of flame atomic absorption spectrometers, in addition to the analysis of samples previously decomposed in strongly oxidizing media.

Some means listed in Table 1 are associated with high standard deviation values, which can be explained by the heterogeneity of the vermicompost matrix. Although the vermicompost was previously homogenized, it was not possible to avoid such deviations considering the vermicompost without going through any sieving step. However, due to the large distancing of the concentration means in the supernatants in relation to the limits established by CONAMA for $\mathrm{Cd}^{2+}, \mathrm{Cu}^{2+}$ and $\mathrm{Ni}^{2+10}$, standard deviation values associated with the concentration means of these cations in the supernatants do not interfere in the interpretation of the adsorbent efficiency of the vermicompost. This statement is also valid for most $\mathrm{Pb}^{2+}$ ions concentrations after the tests under resting conditions. Specifically, for $\mathrm{Zn}^{2+}$ ions, the standard deviation values listed in Table 1 do not render interpretation unfeasible, since the remaining concentrations in the supernatants are higher than or very close to the limit established by CONAMA, which is $5.0 \mathrm{mg} \mathrm{L}^{-110}$.

The initial $\mathrm{pH}$ of the mixed solution used in the first experimental phase was 0.9. However, after the different adsorption procedures, the $\mathrm{pH}$ values of the supernatants ranged from $4.7 \pm 0.3$ (resting tests for $24 \mathrm{~h}$ ) to $6.0 \pm 0.5$ (resting tests for $72 \mathrm{~h}$ ), considering the analysis of four replicates. Thus, in addition to the cations evaluated, the vermicompost also adsorbed $\mathrm{H}_{3} \mathrm{O}^{+}$ions from the mixed solution, with the consequent increase in $\mathrm{pH}$. In turn, this increase in $\mathrm{pH}$ favors the appearance of negative charges on the surface of vermicompost particles, with the consequent potentiation of physical (electrostatic) adsorption among negatively charged adsorption sites and the cations present in the mixed solution. These 
results demonstrate the efficiency of the vermicompost in simultaneously adjusting the $\mathrm{pH}$ of aqueous media to the recommended range (5.0 to 9.0$)^{10}$ and leading to significant reductions in the concentrations of different cations.

Hydrated ionic radius (nm) of cadmium, lead, copper, manganese, nickel and zinc are, respectively, 0.426, 0.401, 0.419, 0.438, 0.404 and $0.430^{8,12}$. The lower the hydrated ionic radius, the higher the ion charge density, considering the same charge as in the case of $\mathrm{Cd}^{2+}, \mathrm{Cu}^{2+}, \mathrm{Mn}^{2+}$, $\mathrm{Ni}^{2+}, \mathrm{Pb}^{2+}$ and $\mathrm{Zn}^{2+}$ ions. Thus, for adsorption processes in which electrostatic interactions contribute significantly, as in adsorption processes in the vermicompost matrix ${ }^{2}$, cations with the highest charge densities will be preferentially adsorbed. Therefore, considering the values of hydrated ionic radius, it is possible to observe why the vermicompost presented lower adsorption efficiencies for $\mathrm{Mn}^{2+}$ and $\mathrm{Zn}^{2+}$, when compared to $\mathrm{Cd}^{2+}, \mathrm{Cu}^{2+}, \mathrm{Ni}^{2+}$ and $\mathrm{Pb}^{2+}$. It should be noted that, although electrostatic interactions play a significant role in adsorbents such as the vermicompost, the formation of covalent bonds with humified organic matter cannot be neglected ${ }^{7}$. In addition to the humified organic matter, the vermicompost matrix has a high aluminosilicate content, with marked cation exchange capacity ${ }^{3}$.

Although the tests of the first experimental phase were not successful for the cations $\mathrm{Mn}^{2+}$ and $\mathrm{Zn}^{2+}$, the retentions of other cations occurred more efficiently when vermicompost particles were under mechanical stirring for a period of $10 \mathrm{~h}$. Thus, mechanical stirring for $10 \mathrm{~h}$ was used in the adsorption tests of the second experimental phase, in which the initial concentrations of $\mathrm{Mn}^{2+}$ and $\mathrm{Zn}^{2+}$ decreased in the mixed solutions, respectively, to 2.0 and $10.0 \mathrm{mg} \mathrm{L}^{-1}$. The decrease in these initial concentrations was adopted to compensate for the lower affinities of the adsorption sites of the vermicompost in relation to both cations. To investigate if smaller initial amounts of $\mathrm{Mn}^{2+}$ and $\mathrm{Zn}^{2+}$ would improve the adsorption efficiency of the vermicompost without mechanical stirring, the second experimental phase also adopted the resting times of $24,48,72$ and $96 \mathrm{~h}$.

The results obtained after the second experimental phase are in Table 2, emphasizing that the analyses were performed to quantify only manganese and zinc. This strategy was adopted since, during the tests conducted in the first experimental phase, the concentrations of $\mathrm{Cd}^{2+}$, $\mathrm{Cu}^{2+}, \mathrm{Ni}^{2+}$ and $\mathrm{Pb}^{2+}$ ions had already been much lower than the respective legal limits ${ }^{10}$. Therefore, the decrease in $\mathrm{Mn}^{2+}$ and $\mathrm{Zn}^{2+}$ concentrations in the second experimental phase could not decrease the satisfactory adsorption of $\mathrm{Cd}^{2+}, \mathrm{Cu}^{2+}, \mathrm{Ni}^{2+}$ and $\mathrm{Pb}^{2+}$ ions, which had been previously observed.

Data in Table 2 demonstrated that the decreases in $\mathrm{Mn}^{2+}$ and $\mathrm{Zn}^{2+}$ ions concentrations to 2.0 and $10.0 \mathrm{mg} \mathrm{L}^{-1}$, respectively, were sufficient to guarantee adsorptions capable of framing treated aqueous media within the requirements of quality standards for effluents ${ }^{10}$. It is important to observe that, although the initial concentrations of $\mathrm{Mn}^{2+}$ and $\mathrm{Zn}^{2+}$ ions decreased in the mixed solution, they remained 2 times higher than their respective legal limits ${ }^{10}$.

Table 2. Concentrations $\left(\mathrm{mg} \mathrm{L}^{-1}\right)$ of manganese and zinc after the second experimental phase*, $\mathrm{N}=4$. Values expressed as Mean \pm standard deviation.

\begin{tabular}{ccc}
\hline \multirow{2}{*}{ Experimental condition } & \multicolumn{2}{c}{ Cation } \\
\cline { 2 - 3 } & $\mathrm{Mn}^{2+}$ & $\mathrm{Zn}^{2+}$ \\
\hline VA** 10 $\mathrm{h}$ & $0.80 \pm 0.04$ & $<0.05^{* * * *}$ \\
VR*** 24 h & $0.90 \pm 0.07$ & $<0.05$ \\
VR 48 h & $0.50 \pm 0.06$ & $<0.05$ \\
VR 72 h & $0.40 \pm 0.01$ & $<0.05$ \\
VR 96 h & $0.6 \pm 0.1$ & $<0.05$ \\
\hline
\end{tabular}

*Experimental conditions: mechanical agitation of vermicompost without sieving $(10.0000 \mathrm{~g})$ at $200 \mathrm{rpm}$ with $50.00 \mathrm{~mL}$ aliquots of mixed solution of $\mathrm{Cd}^{2+}, \mathrm{Cu}^{2+}, \mathrm{Mn}^{2+}, \mathrm{Ni}^{2+}, \mathrm{Pb}^{2+}$ and $\mathrm{Zn}^{2+}(\mathrm{pH} 0.9)$, at the respective concentrations of $2.0 ; 10.0 ; 2.0 ; 20.0 ; 5.0$ and $10.0 \mathrm{mg} \mathrm{L}^{-1}$. **Vermicompost under mechanical agitation. ***Vermicompost at rest. $* * * *$ Lower than the detection limit of the analytical method.

The results from the third experimental phase (use of $0.053 \mathrm{~mm}$ mesh, sieved vermicompost) are listed in Table 3. Here, the experiments were carried out with a mechanical stirring time of $10 \mathrm{~h}$, for reasons previously explained for the procedures of the second experimental phase. 
The results in Table 3 showed that the decrease in the diameter of vermicompost particles (granulometry $\leq 0.053 \mathrm{~mm}$ ) provided a very effective adsorption for $\mathrm{Zn}^{2+}$ ions, since its initial concentration in the mixed solutions was $50 \mathrm{mg} \mathrm{L}$ ${ }^{1}$, or 10 times higher than the legal limit ${ }^{10}$. This observation is also valid for the other cations. Therefore, it is concluded that the increase in the surface area of vermicompost particles considerably minimized the competition effects observed in the first experimental phase for $\mathrm{Zn}^{2+}$.

For $\mathrm{Mn}^{2+}$ ions, the concentrations in the supernatants after the treatment with $0.053 \mathrm{~mm}$ sieved vermicompost were also effective, considering that the initial concentration of $\mathrm{Mn}^{2+}$ in the mixed solutions was $20 \mathrm{mg} \mathrm{L}^{-1}$. However, for most experimental conditions tested, the concentrations of manganese ions were higher than or very close to the maximum limit of this cation $\left(1.0 \mathrm{mg} \mathrm{L}^{-1}\right)^{10}$. Despite these results, the adsorption of $\mathrm{Mn}^{2+}$ ion was much more effective in the third experimental phase than in the first phase, and small increases in the mass of the sieved vermicompost using a $0.053 \mathrm{~mm}$ mesh would be sufficient to adjust $\mathrm{Mn}^{2+}$ concentrations to the limit of CONAMA ${ }^{10}$. The presence of high standard deviation values for some of the means listed in Table 3 can also be interpreted as previously discussed for Table 1.

The results of the first, second and third experimental phases indicated that relatively reduced vermicompost masses can remove significant amounts of the six elements investigated. Considering that the ton of vermicompost can be purchased for about US\$ 100 , it becomes feasible to use larger amounts of that adsorbent, if it is necessary to treat higher volumes of aqueous media. It should be noted, however, that the tests performed used aqueous media at very high concentrations (up to 10 times higher than the legal limits) of the six elements evaluated, so that, in general, real wastewaters have considerably lower concentrations. As discussed below, this was the case of the wastewater of an atomic spectrometry laboratory.

Table 3. Concentrations $\left(\mathrm{mg} \mathrm{L}^{-1}\right)$ of cadmium, copper, manganese, nickel, lead, and zinc after the third experimental phase*, $\mathrm{N}=4$. Values expressed as Mean \pm standard deviation.

\begin{tabular}{ccccccc}
\hline Experimental & \multicolumn{7}{c}{ Cation } \\
\cline { 2 - 6 } condition & $\mathrm{Cd}^{2+}$ & $\mathrm{Cu}^{2+}$ & $\mathrm{Mn}^{2+}$ & $\mathrm{Ni}^{2+}$ & $\mathrm{Pb}^{2+}$ & $\mathrm{Zn}^{2+}$ \\
\hline VA** 2h & $<0.05 * * * *$ & $<0.08$ & $1.4 \pm 0.2$ & $<0.06$ & $<0.2$ & $0.4 \pm 0.03$ \\
VA 10h & $<0.05$ & $<0.08$ & $1.6 \pm 0.8$ & $<0.06$ & $<0.2$ & $0.2 \pm 0.04$ \\
VR*** 24 h & $<0.05$ & $<0.08$ & $1.4 \pm 0.2$ & $<0.08$ & $<0.2$ & $<0.05$ \\
VR 48 h & $<0.05$ & $<0.08$ & $1.0 \pm 0.2$ & $<0.06$ & $<0.2$ & $<0.05$ \\
VR 72 h & $<0.05$ & $<0.08$ & $<0.1$ & $<0.06$ & $<0.2$ & $<0.05$ \\
VR 96 h & $<0.05$ & $<0.08$ & $0.9 \pm 0.1$ & $<0.06$ & $<0.2$ & $<0.05$ \\
\hline
\end{tabular}

*Experimental conditions: mechanical agitation of vermicompost $(10.0000 \mathrm{~g})$ sieved in a $0.053 \mathrm{~mm}$ mesh at $200 \mathrm{rpm}$ with $50.00 \mathrm{~mL}$ aliquots of mixed solution of $\mathrm{Cd}^{2+}, \mathrm{Cu}^{2+}, \mathrm{Mn}^{2+}, \mathrm{Ni}^{2+}, \mathrm{Pb}^{2+}$ and $\mathrm{Zn}^{2+}(\mathrm{pH} 0.9)$, at the respective concentrations of $2.0 ; 10.0 ; 10.0 ; 20.0 ; 5.0$ and $50.0 \mathrm{mg} \mathrm{L}^{-1}$. **Vermicompost under mechanical agitation. $* * *$ Vermicompost at rest. $* * * *$ Lower than the detection limit of the analytical method.

Table 4 lists the concentrations of $\mathrm{Cd}^{2+}, \mathrm{Cu}^{2+}$, $\mathrm{Mn}^{2+}, \mathrm{Ni}^{2+}, \mathrm{Pb}^{2+}$ and $\mathrm{Zn}^{2+}$ ions in the wastewater, whose natural $\mathrm{pH}$ was 5.0. Considering the results listed in Table 4 and those of the first three experimental phases, vermicompost with its natural granulometry and mechanical stirring for $10 \mathrm{~h}$ were used.

Table 4. Concentrations of cadmium, copper, manganese, nickel, lead, and zinc $\left(\mathrm{mg} \mathrm{L}^{-1}\right)$ in a real wastewater $(\mathrm{pH}$ 5.0) derived from an atomic spectrometry laboratory, $\mathrm{N}=4$. Values expressed as Mean \pm standard deviation.

\begin{tabular}{cccccc}
\multicolumn{6}{c}{ Cation } \\
\hline $\mathrm{Cd}^{2+}$ & $\mathrm{Cu}^{2+}$ & $\mathrm{Mn}^{2+}$ & $\mathrm{Ni}^{2+}$ & $\mathrm{Pb}^{2+}$ & $\mathrm{Zn}^{2+}$ \\
\hline $0.3 \pm 0.02$ & $<0.08^{*}$ & $0.15 \pm 0.09$ & $<0.06$ & $1.9 \pm 0.1$ & $0.15 \pm 0.04$ \\
\hline
\end{tabular}

*Detection limit of the analytical method. 
Before the treatment with the vermicompost, the wastewater already had concentrations of $\mathrm{Cu}^{2+}, \mathrm{Mn}^{2+}, \mathrm{Ni}^{2+}$ and $\mathrm{Zn}^{2+}$ ions below the respective legal limits ${ }^{10}$. However, the concentrations of $\mathrm{Cd}^{2+}$ and $\mathrm{Pb}^{2+}$ were, respectively, 1.5 and 3.8 times higher than these limits ${ }^{10}$. After the treatment, the concentrations of $\mathrm{Cd}^{2+}, \mathrm{Cu}^{2+}, \mathrm{Mn}^{2+}, \mathrm{Ni}^{2+}, \mathrm{Pb}^{2+}$ and $\mathrm{Zn}^{2+}$ ions were below the respective detection limits of the analytical methods. The same results were observed when wastewater was acidified with $\mathrm{HNO}_{3}$, thus highlighting the viability of the vermicompost for the treatment of wastewater under different conditions of $\mathrm{pH}$, i.e., at $\mathrm{pH} 5$ (natural $\mathrm{pH}$ ) and 1 (after acidification with $\mathrm{HNO}_{3}$ ).

In a review ${ }^{13}$ concerning the use of vermicompost to treat aqueous media, it is possible to observe a scarcity of studies related to the use of vermicompost to adsorb metallic cations under conditions of high acidity and strong competition among the adsorbates (mixed solutions). However, studies using vermicompost and similar materials (composted solid residues) to retain metallic cations from single aqueous solutions can be used to compare adsorption affinities. In this context, Zhu et al. ${ }^{14}$ evaluated the adsorptive efficiency of vermicompost to retain $\mathrm{Cd}^{2+}$ and $\mathrm{Pb}^{2+}$ ions, and a preferential adsorption of $\mathrm{Pb}^{2+}$ was observed, thus corroborating this study. In turn, two composted municipal solid residues were used to retain $\mathrm{Cu}^{2+}, \mathrm{Pb}^{2+}$ and $\mathrm{Zn}^{2+15}$, and the following adsorption order was observed: $\mathrm{Pb}^{2+}>\mathrm{Cu}^{2+}>\mathrm{Zn}^{2+}$. These results are also in agreement with this study, thus indicating that composted materials (including vermicompost) have similar adsorption profiles, independently of their sources.

Recently, vermicompost derived from cow dung was used to retain $\mathrm{Cu}^{2+}, \mathrm{Fe}^{2+}, \mathrm{Mn}^{2+}$, and $\mathrm{Zn}^{2+}$ ions from effluents of different types of industries (beverage, distillery, and paper mill) ${ }^{16}$, and the following adsorption order was observed: $\mathrm{Cu}^{2+}>$ $\mathrm{Mn}^{2+}>\mathrm{Fe}^{2+}>\mathrm{Zn}^{2+}$. Similarly, to this study, the cited research ${ }^{16}$ indicated a preferential affinity of $\mathrm{Cu}^{2+}$ ions in relation to the chemical groups of the vermicompost, whose masses were of up to $100 \mathrm{~g}$. In general, $100 \mathrm{~g}$ of vermicompost resulted in the highest adsorption percentages, thus underlining that large masses of vermicompost are able to minimize strong chemical competitions in relation to adsorptive chemical groups. The need for higher vermicompost masses was also observed in our investigation, but in a minor scale, since $10 \mathrm{~g}$ of vermicompost were sufficient to assure satisfactory adsorptions for the most investigated metallic cations.

When vermicomposts are submitted to partial extractions of humified substances, humified insoluble solids are produced. The production of this type of solid is important to compare the adsorptive efficiency among vermicomposts with and without chemical modifications. In this context, a humified insoluble solid was used to adsorb $\mathrm{Ni}^{2+}$ and $\mathrm{Pb}^{2+}$ ions from effluents of a white clay factory ${ }^{17}$, and the authors verified adsorptions of $98 \%$ and $96 \%$ for $\mathrm{Ni}^{2+}$ and $\mathrm{Pb}^{2+}$, respectively, considering adsorbent masses of up to $20 \mathrm{~g}$ and $\mathrm{pH}$ 7. This outcome revealed a great difference between the cited research ${ }^{17}$ and our study, in which $10 \mathrm{~g}$ of vermicompost (not submitted to chemical modifications) were sufficient to assure simultaneous and satisfactory adsorptions of the most of six metallic cations $\left(\mathrm{Cd}^{2+}, \mathrm{Cu}^{2+}, \mathrm{Mn}^{2+}\right.$, $\mathrm{Ni}^{2+}, \mathrm{Pb}^{2+}$ and $\mathrm{Zn}^{2+}$ ) even considering high acidity conditions.

Treatment procedures for aqueous media based on adsorption processes, such as the one presented in this study, generate an environmental liability, which is characterized by the adsorbent mass enriched with various metals. Therefore, safe alternatives for the allocation of such environmental liabilities should be carefully evaluated. Thus, the destination of the vermicompost enriched with the execution of this study will be object of future investigations, which will be based on procedures already tested. In this context, previous studies ${ }^{9}$ pointed out that metallic cations adsorbed in the vermicompost can be completely desorbed by percolation of acidic eluents, as $1 \mathrm{~mol} \mathrm{~L}^{-1} \mathrm{HNO}_{3}$ solution. As for the recovery of desorbed metal ions, the literature ${ }^{18}$ points to successful reuse alternatives in the scope of practical classes.

\section{Conclusions}

The results obtained in this study extended the understanding of the interaction forms between metallic cations and the vermicompost, one of the most complex commercially available humified materials. In this context, the use of the vermicompost was very suitable for the removal of $\mathrm{Cd}^{2+}, \mathrm{Cu}^{2+}, \mathrm{Mn}^{2+}, \mathrm{Ni}^{2+}, \mathrm{Pb}^{2+}$ and $\mathrm{Zn}^{2+}$ cations from aqueous media, even considering the high acidity of the mixed solutions tested. This study also showed the suitability of the vermicompost 
for the treatment of a real wastewater from an atomic spectrometry laboratory.

\section{Acknowledgements}

The authors would like to thank the Conselho Nacional de Desenvolvimento Científico Tecnológico (CNPq), the Coordenação de Aperfeiçoamento de Pessoal de Nível Superior (CAPES), and the Fundação de Amparo à Pesquisa do Estado da Bahia (FAPESB) for fellowships and financial support (CNPq: 555522/2006-7 and 620041/2006-4 and FAPESB: APP0076/2009, APP0036/2011 and RED0017/2014).

\section{References}

[1] Nordberg, G. F., Fowler, B. A., Nordberg, M., Friberg, L., Handbook of Toxicology of Metals, $3^{\text {rd }}$ edn., Academic Press: Burlington, 2007, Ch1.

[2] Mitra, S., Sample Preparation Techniques in Analytical Chemistry, $2^{\text {nd }}$ edn., John Wiley \& Sons, Inc.: New Jersey, 2003, Ch1.

[3] Naderi, A., Delavar, M. A., Ghorbani, Y., Kaboudin, B., Hosseini, M., Modification of nanoclays with ionic liquids for the removal of $\mathrm{Cd}(\mathrm{II})$ ion from aqueous phase, Appl. Clay Sci. 158 (2018) 236-245.

https://doi.org/10.1016/j.clay.2018.03.037.

[4] Lee, S. Y., Choi, H. J., Persimmon leaf biowaste for adsorptive removal of heavy metals from aqueous solution, J. Environ. Manag. 209 (2018) 382-392.

https://doi.org/10.1016/j.jenvman.2017.12.080.

[5] Carolin, C. F., Kumar, P. S., Saravanan, A., Joshiba, G. J., Naushad, M., Efficient techniques for the removal of toxic heavy metals from aquatic environment: A review, J. Environ. Chem. Eng. 5 (2017) 2782-2799. https://doi.org/10.1016/j.jece.2017.05.029.

[6] Al-Saydeh, S. A., El-Naas, M. H., Zaidi, S. J., Copper removal from industrial wastewater: A comprehensive review, J. Ind. Eng. Chem. 56 (2017) $35-44$. https://doi.org/10.1016/j.jiec.2017.07.026.
[7] van Loon, G. W., Duffy, S. J., Environmental Chemistry, $2^{\text {nd }}$ edn., Oxford University Press: Oxford, 2005, Ch12.

[8] Essington, M. E., Soil and Water Chemistry An Integrative Approach, CRC Press: Boca Ratton, 2004, Ch7.

[9] Pereira, M. G., Arruda, M. A. Z., Vermicompost as a Natural Adsorbent Material: Characterization and Potentialities for Cadmium Adsorption, J. Braz. Chem. Soc. 14 (1) (2003) 39$47 . \quad$ https://doi.org/10.1590/S010350532003000100007 .

[10] BRASIL, Conselho Nacional do Meio Ambiente (CONAMA). Resolução $n^{\circ} 430$ de 13 de maio de 2011. Lex: Resoluções do CONAMA, Edição especial, p. 420, Brasília-DF, 2012.

[11] Harris, D. C., Análise Química Quantitativa, $7^{\mathrm{a}}$ edição, Livros Técnicos e Científicos Editora S.A: Rio de Janeiro, 2008, Cap5.

[12] Loux, N. T., Anderson, M. A., Mobile ion activities at charged interfaces, Physiochem. Eng. Aspects $177 \quad(2-3) \quad$ (2001) 123-131. https://doi.org/10.1016/S0927-7757(00)00665-8.

[13] Pereira, M. G., de Souza Neta, L. C., Fontes, M. P. F., Souza, A. N., Matos, T. C., Sachdev, R. L., dos Santos, A. V., Souza, M. O. G., de Andrade, M. V. A. S., Paulo, G. M. M., Ribeiro, J, N., Ribeiro, A. V. F. N., An Overview of the Environmental Applicability of Vermicompost: From Wastewater Treatment to the Development of Sensitive Analytical Methods Scientific World Journal 2014 (2014) 1-14.https://doi.org/10.1155/2014/917348.

[14] Zhu, W., Du, W., Shen, X., Zhang, H., Ding, Y., Comparative Adsorption of $\mathrm{Pb}^{2+}$ and $\mathrm{Cd}^{2+}$ by Cow Manure and Its Vermicompos, tEnviron. $\begin{array}{llll}\text { Pollut } & 227 & \text { (2017) 89-97. }\end{array}$ https://doi.org/10.1016/j.envpol.2017.04.048.

[15] Paradelo, R., Barral, M. T., Evaluation of the potential capacity as biosorbents of two MSW composts with different $\mathrm{Cu}, \mathrm{Pb}$ and $\mathrm{Zn}$ concentrations, Bioresource Technol. 104 (2012) 810-813.

https://doi.org/10.1016/j.biortech.2011.11.012.

[16] Singh, J., Kaur, A., Vermicompost as a strong buffer and natural adsorbent for reducing 
transition metals, BOD, COD from industrial effluent, Ecol. Eng. 74 (2015) 13-19. https://doi.org/10.1016/j.ecoleng.2014.10.028.

[17] García, A. C., Izquierdo, F. G., de Amaral Sobrinho, N. M. B., Castro, R. N., Santos, L. A., de Souza, L. G. A., Berbara, R. L. L., Humified insoluble solid for efficient decontamination of nickel and lead in industrial effluents, J. Environ. Chem. Eng. 1 (2013) 916-924. https://doi.org/10.1016/j.jece.2013.08.001.

[18] Piero, P. B., Belizário, M., Tedesco, L. C., Ribeiro, J. N. F. A. V., Tratamento e recuperação de cobre, prata e níquel presentes em resíduos tóxicos oriundos de aulas práticas, Analytica (São Paulo) 8 (2009) 85-93. 